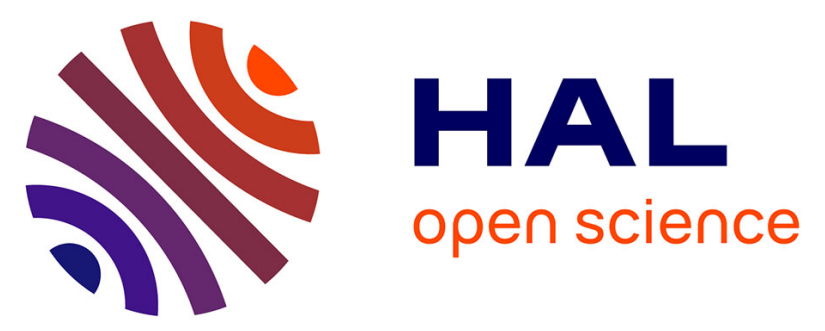

\title{
Concurrent losses of skeletal muscle mass, adipose tissue and bone mineral density during bevacizumab / cytotoxic chemotherapy treatment for metastatic colorectal cancer
}

\author{
Adeline Dolly, Thierry Lecomte, Olivier Bouché, Christophe Borg, Eric \\ Terrebonne, Jean-Yves Douillard, Romain Chautard, William Raoul, David \\ Ternant, Julie Léger, et al.
}

\section{- To cite this version:}

Adeline Dolly, Thierry Lecomte, Olivier Bouché, Christophe Borg, Eric Terrebonne, et al.. Concurrent losses of skeletal muscle mass, adipose tissue and bone mineral density during bevacizumab / cytotoxic chemotherapy treatment for metastatic colorectal cancer. Clinical Nutrition, 2020, S0261-5614 (20), pp.30080-7. 10.1016/j.clnu.2020.02.017 . inserm-02735513

\section{HAL Id: inserm-02735513 https://www.hal.inserm.fr/inserm-02735513}

Submitted on 2 Jun 2020

HAL is a multi-disciplinary open access archive for the deposit and dissemination of scientific research documents, whether they are published or not. The documents may come from teaching and research institutions in France or abroad, or from public or private research centers.
L'archive ouverte pluridisciplinaire HAL, est destinée au dépôt et à la diffusion de documents scientifiques de niveau recherche, publiés ou non, émanant des établissements d'enseignement et de recherche français ou étrangers, des laboratoires publics ou privés. 


\section{Clinical Nutrition}

Original article

\section{Concurrent losses of skeletal muscle mass, adipose tissue and bone mineral density during bevacizumab / cytotoxic chemotherapy treatment for metastatic colorectal cancer}

Adeline Dolly ${ }^{\mathrm{a}}$, Thierry Lecomte ${ }^{\mathrm{b}, \mathrm{c}}$, Olivier Bouche ${ }^{\mathrm{d}}$, Christophe Borg ${ }^{\mathrm{e}}$, Eric Terrebonne ${ }^{\mathrm{f}}$, Jean-Yves Douillard g, Romain Chautard ${ }^{\mathrm{b}, \mathrm{c}}$, William Raoul ${ }^{\mathrm{c}}$, David Ternant ${ }^{\mathrm{c}, \mathrm{h}}$, Julie Leger ${ }^{\mathrm{i}}$, Aurore Bleuzen ${ }^{\mathrm{j}}$, Jean-François Dumas ${ }^{\mathrm{a}}$ ${ }^{1}$, Stephane Servais ${ }^{\text {a, }}{ }^{* *}, 1$, Vickie E. Baracos ${ }^{\text {k, * }}$

a Inserm UMR1069, “Nutrition, Croissance et Cancer”, University of Tours, France

b Department of Hepatogastroenterology and Digestive Oncology, Hôpital Trousseau, CHRU de Tours, 37044, Tours, Cedex 09, France ${ }^{c}$ EA GICC 7501, University of Tours, 10 Boulevard Tonnelle, 37000, Tours, France

${ }^{\mathrm{d}}$ Department of Hepatogastroenterology, Hôpital Robert Debré, CHU de Reims, Avenue General Koenig, 51092, Reims, Cedex, France e Department of Medical Oncology, Hôpital Jean Minjoz, CHRU de Besançon, 3 Boulevard Alexandre Fleming, 25000, Besançon, France ${ }^{\mathrm{f}}$ Department of Hepatogastroenterology and Digestive Oncology, Hôpital du Haut Lévêque, CHU de Bordeaux, Avenue Magellan, 33604 , Pessac Cedex, France

g Department of Medical Oncology, ICO Rene Gauducheau, 44805, Saint-Herblain, France

${ }^{\text {h }}$ Department of Pharmacology \& Toxicology, Hôpital Bretonneau, CHRU de Tours, 37044, Tours, Cedex 09, France

i INSERM CIC 1415, CHRU de Tours, CHRU de Tours, 37044, Tours, Cedex 09, France

j Department of Radiology, Hôpital Bretonneau, CHRU de Tours, CHRU de Tours, 37044, Tours, Cedex 09, France

${ }^{\mathrm{k}}$ Department of Oncology, Division of Palliative Care Medicine, University of Alberta, Edmonton, Canada

* Corresponding author. Division of Palliative Care Medicine, Department of Oncology, University of Alberta, 11560 University Avenue, Edmonton Alberta, T6G 1Z2, Canada, Fax: +1 7804328425.

** Corresponding author. Inserm UMR1069, Nutrition, Croissance et Cancer, Université de Tours 10, boulevard Tonnelle, 37032, Tours, Cedex, France. Fax: +33247366226.

E-mail addresses: stephane.servais@univ-tours.fr (S. Servais), vickie.baracos@ualberta.ca (V.E. Baracos).

${ }^{1}$ Both authors contributed equally to this manuscript. 
Please cite this article as:

Dolly A et al., Concurrent losses of skeletal muscle mass, adipose tissue and bone mineral density during bevacizumab / cytotoxic chemotherapy treatment for metastatic colorectal cancer, Clinical Nutrition,

https://doi.org/10.1016/j.clnu.2020.02.017

\section{Summary}

Background: Changes in skeletal muscle mass (SMM), total adipose tissue mass (TAT) or bone mineral density (BMD) have been described in patients with cancer undergoing various treatments; simultaneous variations of all 3 tissues has not been reported.

Methods: Data were prospectively collected in a clinical study (NCT00489697) including patients with liver metastases of colorectal cancer who received 4 cycles of bevacizumab in combination with cytotoxic chemotherapy. Computerized tomography (CT) at baseline and after chemotherapy was used to quantify skeletal muscle and adipose tissue cross-sectional areas, and mean lumbar spine BMD using validated approaches.

Results: After exclusion of patients lacking adequate CT images or missing data, 72 subjects were included. Patients were $63 \%$ male, aged $63.2 \pm 10.3$ years, $100 \%$ had liver metastases and 54\%, 24\% and 22\% respectively has 0,1 and 2 extrahepatic metastases. $100 \%$ tolerated 4 cycles of treatment and none showed progressive disease at the end of treatment. The scan interval was 70 days (95\% CI, 62.3 to 80.5 ). Thresholds for loss of tissue were defined as loss measurement error. 10\% of patients showed no loss of any tissue and a further $43 \%$ lost one tissue (SMM, TAT or BMD); $47 \%$ of patients lost 2 tissues (16.5\% lost SMM + TAT, 8\% lost SMM + BMD, 10\% lost TAT + BMD) or all 3 tissues $(12.5 \%)$. Catabolic behavior ( 2 or 3 tissue loss vs 0 or 1 tissue loss) associated with disease burden, including unresectable primary tumor $(\mathrm{p}=0.010)$, presence of extrahepatic $(\mathrm{EH})$ metastases $(\mathrm{p}=0.039)$ and number of EH metastases $(\mathrm{p}=0.004)$. No association was found between the number of tissues lost and treatment response, which was uniformly high, or treatment toxicity, which was uniformly low.

Conclusion: Multiple tissues can be measured in routine CT images and these show considerable inter-individual variation. Substantial losses in some individuals appear to associate with disease burden.

Keywords: Bone mineral density, Body composition, Colorectal cancer, Chemotherapy, CT-Scan, Skeletal muscle

Abbreviations: BMD, Bone Mineral Density; EH, Extra-Hepatic; mCRC, metastatic Colorectal Cancer; SMM, Skeletal Muscle Mass; SMI, Skeletal Muscle Index; TAT, Total Adipose Tissue. 


\section{Introduction}

Using diagnostic, staging or follow-up CT-Scans, skeletal muscle mass (SMM) change in patients with cancer has been investigated, especially in gastrointestinal and lung cancers. Muscle loss occurs in patients on platinum[1-4], taxane- or fluoropyrimidine-based treatments [3,5,6], and various regimens of neoadjuvant/adjuvant treatment $[7,8]$. In metastatic colorectal cancer (mCRC), with bevacizumab \pm oxaliplatin- or irinotecan-based combination chemotherapy, an overall decrease in SMM was observed within 2e6 months of treatment [9-12], except in one recent study where it remained unchanged [13] (Table 1). Various patterns have emerged concerning adipose tissue (AT) during cancer treatment. Alongside a decrease of SMM, Nattenmüller et al. observed an increase of all AT compartments (total, visceral, subcutaneous and intermuscular) after different regimens of 1st linechemotherapy in lung cancer patients [3], while Awad et al. found that patients with oesophagogastric cancer lost SM and fat mass after neoadjuvant platinum-based chemotherapy [4]. Concurrent losses of SM and AT were also observed in other studies $[1,2,8,14]$.

Bone Mineral Density (BMD) loss is considered an issue in gynecological and breast cancers in pre- and post-menopausal women at risk for osteoporosis. BMD is generally assessed by Dual-energy X-ray absorptiometry (DXA) in the lumbar spine, hip and/or femoral neck. Patients on a variety of cancer treatments showed significant loss of BMD [15-19] (Table 2), which was at least partly prevented with calcium and vitamin D supplementation [20]. While muscle and fat are often studied together, investigations of BMD are entirely separate, without attention to soft tissue behavior. Investigations in which multiple tissue losses have been followed concurrently are very few. Kazemi-Bajestani et al. found concurrent losses of muscle, fat and left ventricular mass in non-small cell lung cancer patients on carboplatin-based 1st line therapies [1].

There is experimental data to suggest interactions among changes in muscle, bone and fat described above. Specific catabolic and anabolic effector molecules may have common effects on these tissues, or may participate in cross-talk be-tween them. Bidirectional interactions between muscle and bone are suggested [21,22]. In the context of cancer with bone metastases, osteolysis induces the secretion of activin and TGFb, mediators of muscle proteolysis [23]. Conversely, secretion of IL-15 by muscle seems to increase bone mineral con-tent [24]. The NF-kB pathway has also been identified as being able to regulate both muscle and bone catabolism [25]. While AT secretes adipokines that may have a direct effect on muscle metabolism [26], release of myokines from muscle, such as IL- 6 and IL-15, may disrupt AT metabolism [27]. These signals are part of a reciprocal regulation loop between SMM and AT [28]. Lastly, specific chemotherapy-induced tissue losses have been described in skeletal [29], respiratory and cardiac muscle [30], subcutaneous, abdominal fat [31] as well as BMD [32].

We aimed to evaluate the evolution of muscle mass, adipose tissue and BMD in a population of patients with mCRC treated with bevacizumab and cytotoxic chemotherapy. We hypothesized that simultaneous variations of SM, AT and BMD occur, affected by both cancer treatment and the disease itself, and are associated with poor treatment response and toxicity.

\section{Patients and methods}

\subsection{Study design and patients}

Data were prospectively collected in a French multicenter, nonrandomized study designed to evaluate whether contrast-enhanced ultrasound imaging predicts the efficacy of bevacizumab on colorectal cancer with hepatic metastases (mCRC) (STIC-Avastin, NCT00489697) [33], sponsored by the University Hospital of Tours. This study was in accordance with the code of ethics of the World Medical Association. Patients were enrolled between January 2007 and December 2010, with follow-up until December 2012. Inclusion criteria were: adult patients with histologically confirmed colorectal tumor with hepatic metastases; starting 1st line treatment bevacizumab-based chemo-therapy; life expectancy $>2$ months; World Health Organization (WHO) performance status $\leq 2$; absence of major surgery within 28 days of starting bevacizumab. Exclusion criteria included no hepatic lesion detected by conventional ultrasonography, prior chemotherapy for metastatic colorectal cancer (adjuvant chemotherapy was permitted if terminated for more than 6 months), cardiac disease and any contraindication to bevacizumab treatment. Eligible patients received bevacizumab plus chemotherapy (chosen at the clinician's discretion: single-agent fluoropyrimidine or fluoropyrimidine plus oxaliplatin or irinotecan) until disease progression or unacceptable toxicity occurred, according to the investigator's assessment. The bevacizumab dose was $5 \mathrm{mg} / \mathrm{kg}$ body weight every 2 weeks (5-FU-based regimens) or $7.5 \mathrm{mg} / \mathrm{kg}$ every 3 weeks (capecitabine-based regimens).

\subsection{CT-scan analyses}

Computerized tomography (CT) studies were done to evaluate tumor response according to RECIST (Response Evaluation Criteria in Solid Tumors) criteria [34]; these scans were also used to determine body composition. CT analysis of the lumbar (L3) muscle area has been thoroughly validated [35-37]. Assessments were made on CT images as specified in the study protocol, at baseline (within 2 weeks of before and at two months after the start of bevacizumab-based chemotherapy [33]). One axial image at the 3rd lumbar vertebra was selected for analysis of total muscle and fat crosssectional areas $\left(\mathrm{cm}^{2}\right)$ [36-39]. CT image parameters included: contrastenhanced, 2e5 mm slice thickness, $120 \mathrm{kVp}$, and $\sim 200-400 \mathrm{~mA}$. Contrast alters tissue radiodensity [40,41] and thus only contrast-enhanced images were included and these were typically in portovenous phase. Observers were blinded to the patients' treatment status. Tissues were identified anatomically and quantified within pre-specified Hounsfield unit (HU) ranges [39]: muscle ( -29 to $+150 \mathrm{HU})$; subcutaneous fat $(-190$ to $-30 \mathrm{HU})$; visceral fat $(-150$ to -50 HU) using Slice-O-Matic software (v.5.0; Tomovision, Magog, Canada). Total muscle and fat cross-sectional areas $(\mathrm{cm} 2)$ were computed. 
Table 1

Recent studies describing evolution of skeletal muscle and adipose tissue in colorectal cancer.

\begin{tabular}{|c|c|c|c|c|}
\hline Author, year & Cancer, Population & Chemotherapy & Length of measurements & Body composition findings \\
\hline $\begin{array}{l}\text { Antoun et al. } 2019 \\
\text { [13] }\end{array}$ & $\begin{array}{l}\text { CRC } \\
\text { Metastatic } \\
N=76(50 \% \delta)\end{array}$ & XEURI or FOLFRI & $\begin{array}{l}2 \text { and } 4 \text { months of treatment } \\
\text { follow-up }\end{array}$ & $\begin{array}{l}57 \text { patients with follow-up CT-Scans. No significant change in weight, } \\
\text { SMM and VAT during the } 4 \text { months of follow-up. Decrease in women } \\
\text { only, in SMD between } 2 \text { and } 4 \text { months ( }-6.8 \text { HU, } p=0.012) \text {, and SAT } \\
\text { after } 4 \text { months }\left(-15.4 \mathrm{~cm}^{2} / \mathrm{m}^{2}, p=0.03\right) \text {. }\end{array}$ \\
\hline $\begin{array}{l}\text { Sasaki et al. } 2019 \\
\text { [9] }\end{array}$ & $\begin{array}{l}\text { CRC } \\
\text { Metastatic } \\
N=219(65 \% \delta)\end{array}$ & $\begin{array}{l}\text { Combination chemotherapy regimen } \\
\text { containing mFOLFOX6, POLFIRI, Bevacizumab, } \\
\text { XELOX, SOX or XEURI }\end{array}$ & $\begin{array}{l}3 \text { and } 6 \text { months after systemic } \\
\text { chemotherapy } \\
\text { administration }\end{array}$ & $\begin{array}{l}31 \text { patients } / 142(22 \%) \text { with }>9 \% \text { SMM loss at } 3 \text { months } 21 \text { patients } / 87 \\
\text { (24\%) with }>9 \% \text { SMM loss at } 6 \text { months. No difference regarding VFA and } \\
\text { SFA between patients with or without SMM loss. }\end{array}$ \\
\hline $\begin{array}{l}\text { Kurk et al. } 2018 \\
{[10]}\end{array}$ & $\begin{array}{l}\text { CRC } \\
\text { Metastatic } \\
N=450(63 \% \text { ठ) }\end{array}$ & Capecitabine + oxaliplatin + bevacizumab & $\begin{array}{l}\text { Median interval: } 4.3 \text { months } \\
\text { (IQR: } 4.0 \text { to } 4.5 \text { ) } \\
6 \text { cycles initial of treatment }\end{array}$ & $\begin{array}{l}\text { Decrease in SMM ( }-0.69 \mathrm{~kg} .95 \% \mathrm{C},-1.11 \text { to }-0.26) \text { and body weight } \\
(-0.05 \mathrm{~kg} \text {. } 95 \% \mathrm{a},-0.54 \text { to } 0.45) \\
\text { Using } 2 \% \text { as cutoff value, } 43 \% \text { of patients lost SMM, } 24 \% \text { were stable and } \\
33 \% \text { gained SMM. }\end{array}$ \\
\hline $\begin{array}{l}\text { Blauwhoff- } \\
\text { Buskermolen } \\
\text { et al. } 2016[11]\end{array}$ & $\begin{array}{l}\text { CRC } \\
\text { Stage IV } \\
N=67(63 \% \text { ठ) }\end{array}$ & $\begin{array}{l}\text { Capecitabine } \pm \text { oxaliplatin, } \\
\text { irinotecan, bevacizumab } \\
\text { or Irinotecan } \\
\text { or FU }+ \text { oxaliplatin } \pm \text { bevacizumab }\end{array}$ & $\begin{array}{l}\text { Median interval: } 78 \text { days (IQR: } \\
67 \text { to } 92 \text { ) } \\
\text { Before and during treatment } \\
\text { CT-Scans }\end{array}$ & $\begin{array}{l}\text { Decrease in SMA in both men and women by } 6.1 \%(95 \% \mathrm{Cl},-8.4 \text { to }-3.8 \text {, } \\
p<0.001) \\
\text { Significant decrease of body weight in women by } 4.4 \%(95 \% \mathrm{Cl},-8.5 \\
\text { to }-0.4, p=0.031) \text { but not in men }\end{array}$ \\
\hline $\begin{array}{l}\text { Poterucha et al. } \\
2012 \mid 12]\end{array}$ & $\begin{array}{l}\text { CRC } \\
\text { Metastatic } \\
N=57(53 \% \delta)\end{array}$ & $\begin{array}{l}\text { Bevacizumab for all patients + } \\
\text { FU + oxaliplatin + leucovorin } \\
\text { or irinotecan-based regimen } \\
\text { or capecitabine } \\
\text { or } 5 \text {-FU + leucovorin }\end{array}$ & $\begin{array}{l}\text { Within } 3 \text { months of starting } \\
\text { chemotherapy }\end{array}$ & $\begin{array}{l}\text { Overall decrease in body weight and SMA. } \\
\text { Mean body weight on the first and second CT-Scans were } 85 \mathrm{~kg} \text { (SD, 19) } \\
\text { and } 83 \text { (SD, 19) respectively }(p=0.002) .22 \text { patients gained weight. } \\
\text { Mean SMA on the first and second CT-Scans were } 148 \mathrm{~cm}^{2} \text { (SD, 38) and } \\
145 \mathrm{~cm}^{2} \text { (SD, 39) respectively }(p=0.02) .24 \text { patients gained SMA. }\end{array}$ \\
\hline $\begin{array}{l}\text { Lieffers et al. } 2009 \\
\quad[14]\end{array}$ & $\begin{array}{l}\text { CRC } \\
\text { Metastatic } \\
N=34(65 \% \text { \&) }\end{array}$ & Any 1 st, 2 nd or 3 rd line regimen & $\begin{array}{l}\text { Year of death, } 12,10,6 \text { and } 1.5 \\
\text { months to death }\end{array}$ & $\begin{array}{l}\text { One month from death, concurrent losses of muscle }(4.2 \mathrm{~kg}) \text { and fat } \\
(3.5 \mathrm{~kg})(p<0.05) \text { were observed, as well as increase in liver weight } \\
(0.74 \mathrm{~kg} . p=0.010) \text {. }\end{array}$ \\
\hline
\end{tabular}

CRC: Colorectal Cancer; 5-FU: 5-Fluorouracil; FOLFIRI: 5-Fluorouracil plus Leucovorin plus Irinotec an; mFoLFOX6: 5-Fuorouracil plus Leucovorin plus modified Oxalipl atin; SOX: S-1 plus Oxaliplatin; XEUR: Capecitabine plus Ininotecan: XELOX: Capecitabine plus Oxaliplatin.

Cl: Confidence Interval; HU: Hounsfield Unit; SD: Standard Deviation; SFA: Subcutaneous Fat Area: SMA: Skeletal Muscle Area: SMD: Skeletal Muscle Density: SMM: Skeletal Muscle Mass; VFA: Visceral Fat Area.

Table 2

Recent studies describing evolution of bone mineral density in women with gynecological or breast cancers.

\begin{tabular}{|c|c|c|c|c|}
\hline Author, year & Cancer, Population & Chemotherapy & Length of measurements & Body composition's findings \\
\hline Lee et al. 2016 [15] & $\begin{array}{l}\text { Gynecological cancer } \\
\text { Ovarian: Stage Ic to IV } \\
\text { Uterine endometrial: Stage Ia to IV } \\
\text { Cervical Stage: Ib to IV } \\
N=118 \\
\text { Pre and post-menopausal }\end{array}$ & $\begin{array}{l}\text { Adjuvant } \\
\text { Radiation therapy or chemotherapy } \\
\text { Including platinum-based }\end{array}$ & $\begin{array}{l}12 \text { months after treatment } \\
\text { DXA }\end{array}$ & $\begin{array}{l}\text { Loss of femur neck and lumbar spine BMD T-scores in the } \\
\text { Uterine Endometrial cancer subgroup. }\end{array}$ \\
\hline $\begin{array}{l}\text { Monroy-Cisneros } \\
\text { et al. 2016 [20] }\end{array}$ & $\begin{array}{l}\text { Breast cancer } \\
\text { Stage I to IIIb } \\
N=40 \\
\text { Pre and post-menopausal }\end{array}$ & $\begin{array}{l}\text { Neoadjuvant, adjuvant } \\
\text { FAC, FEC, FAC }+ \text { P, FA, DAC } \\
\pm \text { radiotherapy }\end{array}$ & $\begin{array}{l}6 \text { months of treatment } \\
\text { DXA }\end{array}$ & $\begin{array}{l}\text { Loss of femoral neck }\left(-0.018 \mathrm{~g} / \mathrm{cm}^{2}, 95 \% \mathrm{Cl},-0.026 \text { to }-0.011\right) \\
\text { and lumbar spine } \mathrm{BMD}\left(-0.048 \mathrm{~g} / \mathrm{cm}^{2}, 95 \% \mathrm{Cl}-0.063 \text { to }-0.033\right) \\
\text { (both } p<0.001 \text { ) } \\
\text { Protective effect of calcium + vitamin D supplementation on } \\
\text { femoral neck BMD }\end{array}$ \\
\hline $\begin{array}{l}\text { Oostra et al. } 2015 \\
\text { [16] }\end{array}$ & $\begin{array}{l}\text { Breast cancer with ovarian failure } \\
\text { Stage I, II } \\
N=40 \\
\text { Pre-menopausal }\end{array}$ & $\begin{array}{l}\text { Adjuvant } \\
\text { Cyclophosphamide }+ \text { methotrexate }+ \text { fluorouracil } \\
\text { Cyclophosphamide }+ \text { doxorubicin } \pm \text { fluorouracil } \\
\text { or paclitaxel }\end{array}$ & $\begin{array}{l}6 \text { and } 12 \text { months after treatment } \\
\text { DXA }\end{array}$ & $\begin{array}{l}\text { Loss of lumbar spine BMD (median at baseline: } 0.993 \mathrm{~g} / \mathrm{cm}^{2}, 6 \\
\text { months: } 0.976 \mathrm{~g} / \mathrm{cm}^{2}, 12 \text { months: } 0.937 \mathrm{~g} / \mathrm{cm}^{2} \text { both } p<0.001 \text { ) }\end{array}$ \\
\hline $\begin{array}{l}\text { Cameron et al. } 2010 \\
{[17]}\end{array}$ & $\begin{array}{l}\text { Breast cancer } \\
\text { Early-stage } \\
N=41 \\
\text { Pre-menopausal }\end{array}$ & $\begin{array}{l}\text { Adjuvant } \\
\text { CMF, AC, A, E, FEC-T, EC-T, TACT, TANGO }\end{array}$ & $\begin{array}{l}6 \text { and } 12 \text { months after treatment } \\
\text { DXA }\end{array}$ & $\begin{array}{l}\text { Loss of lumbar spine BMD (mean at basel ine: } 1.05 \pm 0.02 \mathrm{~g} / \mathrm{m}^{2}, 6 \\
\text { month: } 1.01 \pm 0.02 \mathrm{~g} / \mathrm{m}^{2}, 12 \text { months: } 1.00 \pm 0.02 \mathrm{~g} / \mathrm{m}^{2} \text { both } \\
p<0.001 \text { ) }\end{array}$ \\
\hline Hui et al. 2010 [18] & $\begin{array}{l}\text { Gynecological cancer (ovarian, } \\
\text { endometrial, cervical) } \\
N=40\end{array}$ & $\begin{array}{l}\text { Platinum-based } \\
\text { Taxane-based } \\
\pm \text { radiotherapy }\end{array}$ & $\begin{array}{l}7 \text { and } 12 \text { months after initial } \\
\text { course of treatment } \\
\text { CT-Scans }\end{array}$ & $\begin{array}{l}\text { Loss of lumbar spine and femoral neck vBMD after } \\
\text { chemotherapy }(-15.9 \% \pm 5.67 \text { and }-10.4 \% \pm 4.06 \text { respectively })\end{array}$ \\
\hline $\begin{array}{l}\text { Hadji et al. } 2009 \\
\text { [19] }\end{array}$ & $\begin{array}{l}\text { Breast cancer } \\
\text { Non metastatic } \\
N=53 \\
\text { Pre-menopausal }\end{array}$ & Doxorubicin/cyclophosphamide & $\begin{array}{l}6 \text { and } 12 \text { months after treatment } \\
\text { DXA }\end{array}$ & $\begin{array}{l}\text { Loss of lumbar spine }(-5.17 \%, p=0.001) \text {, total hip }(-4.02 \% \\
p=0.001) \text { and femoral neck }(-2.79 \%, p=0.02) \text { BMD at } 12 \\
\text { months from baseline }\end{array}$ \\
\hline
\end{tabular}

A: Doxorubicin; AC: Doxorubicin plus Cyclophosphamide: CMF: Cyclophosphamide plus Methotrexate plus 5-Fluorouracil; DAC: Docetaxel plus Adriamicin plus Cyclophosphamide; E: Epinubicin; EC-T: Epirubicin plus Cyclophosphamide, followed by Paclitaxel; FA: 5-Fuorouracil plus Adriamicin (plus Cyclophosphamide: FAC, plus Paclitaxel: FAC + P): FEC: 5-Fluorouracil plus Epirubicin plus Cyclophosphamide (followed by Docetaxel: FEC-T); TACT: Taxotere as Adjuvant Chemotherapy Trial; TANCO: tAnCo trial (Paclitaxel-containing. Epirubicin-based chemotherapy).

BMD: Bone Mineral Density: vBMD: Volumetric BMD; DXA: Dual-energy X-ray absorptiometry. 
Cross-sectional area of total muscle was normalized for stature, and skeletal muscle index (SMI; $\mathrm{cm}^{2} / \mathrm{m}^{2}$ ) was calculated [36,37]. We used validated cut points for sarcopenia [42]: SMI $<43$ or $53 \mathrm{~cm}^{2} / \mathrm{m}^{2}$ for men with BMI respectively below or over $25 \mathrm{~kg} / \mathrm{m}^{2}$; SMI $<41 \mathrm{~cm}^{2} / \mathrm{m}^{2}$ for all women. Patients with a SMI below these cut-points were considered sarcopenic.

Mean lumbar spine Bone Mineral Density (BMD) from 1st to 3rd lumbar vertebrae was assessed. For each vertebra, we selected two to four consecutive images and used a phantom-less calibration technique $[43,44]$ to assess spine BMD. This method is based on known linear attenuation coefficients of subcutaneous adipose tissue and paraspinal muscle that can be used as internal reference standards to convert the mean trabecular bone CT attenuation and give a BMD estimation in $\mathrm{mg} / \mathrm{cm}^{3}$ [43,44]. With the ROI manager in ImageJ software (ImageJ $1.52 \mathrm{~h}$; Wayne Rasband, National Institutes of Health, USA), three elliptical Regions of Interest (ROI) were placed in the subcutaneous adipose tissue, the paraspinal muscle and the body trabecular bone (Fig. 1). The ROI size was constant from one patient to another, they were manually positioned according to patient morphology. CT number for each tissue ROI corresponding to the peak of a normal Gaussian distribution was collected and the BMD value was calculated. We found a mean intra-observer coefficient of variation of $8 \%$ for BMD in a random sample of 40 patients. STIC Avastin investigation was not originally planned to include analyses of BMD. Therefore, the phantom-less technique was performed as described in several studies $[43,44]$.

To address this limitation and confirm our BMD data, we collected a calibration external reference phantom for 4 CT-scanners available in CHRU of Tours: SIEMENS SOMATON Force, SIEMENS SOMATON Definition AS+, GE Discovery CT750 HD and TOSHIBA B15. We used an external phantom containing several density plugs and created for each CT-Scanner, a calibration curve which maps $\mathrm{CT}$ attenuation in $\mathrm{HU}$ to bone mineral density in $\mathrm{mg} / \mathrm{cm}^{3}$. This method is called asynchronous quantitative computed tomography (QCT) [45e48]. We observed no significant difference between these 4 CT-Scanners (data not shown). Once again, since the analysis of BMD was secondary in STIC Avastin study, no external reference phantom was used with the CT-Scanners of the study. Therefore, we used the calibration curves obtained with the QCT Scans mentioned above to assess spine BMD for each patient.

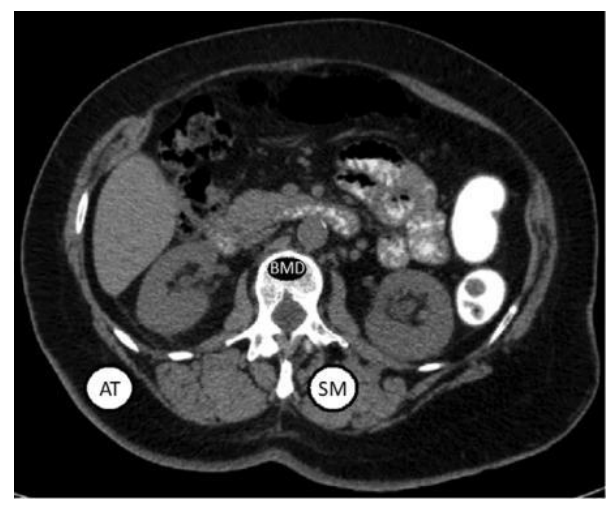

Fig. 1. Phantom-less calibration technique to estimate spine Bone Mineral Density. Manual placement of the Regions of Interest in the subcutaneous adipose tissue, the paraspinal muscle and the body trabecular bone. AT: Adipose Tissue; BMD: Bone Mineral Density; SM: Skeletal Muscle.
We then compared these data to those obtained with the phantom-less calibration technique.

Men and women with a BMD below $120 \mathrm{mg} / \mathrm{cm}^{3}$ were considered osteopenic [49].

\subsection{Treatment response and survival}

Tumor response to chemotherapy was evaluated by means of CT-scans at baseline and follow-up. Best treatment response was assessed using RECIST guidelines [34], as complete response: disappearance of all lesions; partial response: at least a $30 \%$ decrease in the sum of diameters of metastases, compared to baseline sum diameters; stable disease: between $20 \%$ increase and 30\% decrease; progressive disease: at least a $20 \%$ increase in the sum of diameters of metastases, compared to the smallest sum on study.

Overall Survival (OS) was defined as the time from first infusion of bevacizumab-based chemotherapy until death. If a patient didn't meet this outcome (s)he was censored at the date of the last known follow-up visit.

\subsection{Toxicity monitoring}

The primary goal of STIC Avastin investigation was to evaluate the pharmacodynamics of bevacizumab. Data regarding toxicity of cytotoxic chemotherapy were not collected. Patients were evaluated for adverse events attributable to bevacizumab [50,51]: Hypertension, Proteinuria, Low level of Hemoglobin, Hemorrhage, Epitaxis, Cardiac Ischemia, Heart Failure, Thrombosis/Embolism, Arterial Thrombosis, Wound Healing, Cerebral Ischemia, Gastrointestinal Perforation. This was done according to the National Cancer Institute Common Terminology Criteria for Adverse Events (NCI-CTCAE), version 3.0 [52]. They were monitored at the first day of every chemotherapy cycle (every two or three weeks) until 2 months from baseline, and every two to three months afterwards until the end of the firstline bevacizumab-based chemotherapy (maximum 12 long-term follow-ups). We included grade 1-3 toxicities. Grade 3 adverse events were not frequent enough to narrow down the analysis.

\subsection{Other analysis}

Blood samples were collected 1e8 days before the first bevacizumab infusion. Baseline Vascular Endothelial Growth Factor (VEGF) plasma concentrations were measured for each patient with an ELISA kit (R\&D Systems, Minneapolis, MN, USA), as described in Caulet et al. 2016 [53].

\subsection{Statistics}

Statistical analyses were performed using GraphPad Prism software for Windows (v.6.01, La Jolla, California, USA) and Excel XLSTATS by Addinsoft (v.2019.1.2, Boston, USA). D'Agostino \& Pearson omnibus normality tests were performed to test for normal Gaussian distribution of continuous variables. We used nonparametric Wilcoxon-Mann-Whitney tests (with median and inter-quartile range (IQR)) and univariate Spearman correlations coefficients to compare non-normal continuous variables. For variables with a normal distribution, we used parametric $\mathrm{t}$ tests (with mean and standard deviation (SD)) and univariate Pearson correlations coefficients. We considered $\mathrm{p} \leq 0.05$ to be statistically significant.

Regression analysis were performed to test associations be-tween tissues lost both individually and collectively during chemotherapy and parameters including baseline patients' characteristics, hematological clinical parameters, tumor growth and treatment toxicity. 
Survival analyses were performed using Excel XLSTATS by Addinsoft (v.2019.1.2, Boston, USA). We plotted percent survival at each time with Kaplan-Meier survival curves and compared them with log-rank tests. Median survival was defined as the time at which the survival curve crosses $50 \%$ survival, even if data from some subjects were censored.

\section{Results}

Of 137 patients who participated in the STIC-AVASTIN investigation, 72 were included in the current analysis (Fig. 2). The main reasons for exclusion were missing or inadequate CT-Scan $(n=58$ - including 6 patients excluded from analysis of BMD, owing to technical artefact in the images) and failure to complete the treatment plan $(\mathrm{n}=7)$.

\subsection{Baseline characteristics}

Patient characteristics are described in Table 3. Overall, $62.5 \%$ of the participants were men and the mean age was $63.2 \pm 10.3$ years. The majority of patients had primary tumor localized in colon (76\%) and $60 \%$ had their primary tumor resected; $40 \%$ had measurable extra-hepatic (EH) metastases, which were mainly localized in peritoneum, lung and lymph nodes (for respectively $18 \%, 32 \%$ and $32 \%$ of EH-metastatic patients). No bone metastases was measurable in any patient.

The most common chemotherapy was FOLFIRI (irinotecan with infusional leucovorin (LV) and 5-fluorouracil (5-FU)), for 65\% of the cohort. Another $10 \%$ received FOLFOX (oxaliplatin with LV and 5-FU) and the remaining $25 \%$ received several different regimens of chemotherapy (Table 3). A single male participant was taking treatment for osteoporosis: bisphosphonate zoledronic acid (Zometa $\odot$ ), in association with his chemotherapy regimen. Since the analysis of BMD was not planned when STIC Avastin study was designed, no data regarding patients' medication history that might affect BMD was available.

137 patients included

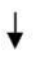

79 patients with two CT-Scans suitable for analysis

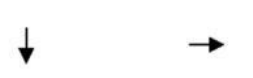

72 patients analyzed meeting inclusion criteria for this study

\section{8 patients excluded: lacking suitable CT-Scans or CT-Scans history \\ - missing baseline $(\mathrm{n}=41)$ or follow-up image $(\mathrm{n}=9)$ \\ - CT-Scans not contrast-enhanced $(\mathrm{n}=2)$ \\ - Technical artefact in CT-Scans $(\mathrm{n}=6)$}

7 patients excluded: not completing treatment plan

- died while on treatment $(\mathrm{n}=4)$

- missing data $(\mathrm{n}=3)$

\section{2 patients partially excluded from the toxicity analysis \\ - One after the fourth cycle of chemotherapy, because of dose- reduction \\ - One with missing data after the second and third cycles of chemotherapy}

Fig. 2. Flow-chart showing patient selection. The main reason for exclusion was lack of CT scans or CT scans not suitable due to artefact or lack of contrast enhancement. Seven patients did not complete the treatment plan i.e. 4 cycles of bevacizumab-based chemotherapy.
Expected differences in body composition were observed be-tween men and women (Table 3). Compared to men, women had lower BMI (22.9 \pm 3.9 $\mathrm{kg} / \mathrm{m}^{2}$ versus $\left.25.1 \pm 3.6 \mathrm{~kg} / \mathrm{m}^{2}, \mathrm{p}=0.019\right), \mathrm{SM}$ area $\left(97.5 \pm 13.9 \mathrm{~cm}^{2}\right.$ versus $\left.148.8 \pm 23.8 \mathrm{~cm}^{2}, \mathrm{p}<0.0001\right)$ and SMI $\left(37.4 \pm 5.3 \mathrm{~cm}^{2} / \mathrm{m}^{2}\right.$ versus $49.3 \pm 7.2$ $\left.\mathrm{cm}^{2} / \mathrm{m}^{2}, \mathrm{p}<0.0001\right)$. Sarcopenia was present in $68 \%$ of patients. No significant difference observed for TAT area, or BMD. A quarter of patients were considered osteopenic at baseline.

\subsection{Bone mineral density measurements methodical equivalence}

Correlations of spine BMD measurements estimated with the phantomless calibration technique and asynchronous QCT technique showed that BMD values were highly correlated at both baseline (Spearman, $\mathrm{p}<0.0001, \mathrm{r}$ $=0.992$ ) and after chemotherapy (Pearson, $\mathrm{p}<0.0001, \mathrm{r}=0.992)$ (Fig. 3).

\subsection{Changes in muscle mass, fat mass and BMD}

The 72 patients included all reached the 2 nd time point and had a CT-scan with a median duration interval of 70 days (95\% CI, 62.3 to 80.5). Data for change over time were normalized to 70 days. For each tissue, patients who experienced tissue loss greater than the measurement error (2\% for SMM and TAT [54], and 8\% for BMD), were categorized as tissue losers. Other patients were categorized as stable/gaining tissue over time. Tissue loss distribution is illustrated according to these categories in Fig. 4A. Tissue losses resulted in 3 men becoming sarcopenic, and 5 men and 3 women becoming osteopenic. Half of patients who were sarcopenic at baseline had further reduction in muscle mass during treatment, while $42 \%$ of patients who were osteopenic at baseline had further decrease in BMD.

Tissue losses were frequently simultaneous, as illustrated by a Venn diagram in Fig. 4B which displays the overlap of patients with SMM, TAT and BMD losses. Ten percent of 72 patients showed no loss of any tissue and $43 \%$ showed isolated loss of a single tissue, with no predominance of any tissue in particular (10.0\% lost SMM, 16.5\% lost TAT and 16.5\% lost BMD). By contrast, a subset (12.5\% of patients) showed concomitant loss of SMM, TAT and BMD; the remaining $34.5 \%$ lost two tissues: $16.5 \%$ lost SMM + TAT, $8 \%$ lost SMM + BMD and 10\% lost TAT + BMD. Figure 4C illustrates correlation between change in skeletal muscle versus change in body weight over 4 cycles of treatment. These were moderately correlated (Spearman rvalue of $0.521, \mathrm{p}<0.001$ ). Likewise, in Fig. 4D the correlation between change of muscle and change of fat over time was significant but with very modest Pearson r-value of 0.403 . Mean muscle radiodensity, a parameter related to survival in patients with solid tumors [42], did not show variation over time (data not shown).

\subsection{Predictors of concurrent tissue loss}

We conducted bivariate regression analysis comparing patients with concomitant loss of SMM, TAT and BMD, or two of these tissues, with those having lost none or a single tissue (Table 4). Tumor characteristics associated with the number of tissues lost. A higher percentage of patients with 2 or 3 tissues lost, still had the primary tumor in place $(56 \%$ versus $26 \%, \mathrm{p}=0.010)$ and presented extra-hepatic (EH) metastases $(53 \%$ versus $29 \%, \mathrm{p}=0.039)$, compared to patients with none or 1 tissue lost. The greater the number of $\mathrm{EH}$-metastases, the greater the number of tissues lost $(\mathrm{p}=0.004)$. Serum VEGF levels, which reflect tumor mass, tend to associate with the number of tissues lost $(\mathrm{p}=0.060)$. However, no difference was found regarding patients' age and sex. 
Table 3

Patient characteristics

\begin{tabular}{|c|c|c|c|c|c|c|c|}
\hline \multirow[t]{2}{*}{ Characteristic } & \multicolumn{3}{|c|}{ Men $(n=45)$} & \multicolumn{3}{|c|}{ Women $(\mathrm{n}=27)$} & \multirow[t]{2}{*}{$p$ value } \\
\hline & No. (\%) & $\begin{array}{l}\text { Mean } \\
\text { Median }\end{array}$ & $\begin{array}{l}\mathrm{SD} \\
\mathrm{IQR}\end{array}$ & No. (\%) & Mean & SD & \\
\hline Age, years & & 64.2 & 10.5 & & 61.4 & 9.8 & 0.255 \\
\hline Primary tumor & & & & & & & 0.778 \\
\hline Colon & $35(78)$ & & & $20(74)$ & & & \\
\hline Rectum & $10(22)$ & & & $7(26)$ & & & \\
\hline Resection of the primary tumor & & & & & & & 0.329 \\
\hline Yes & $29(64)$ & & & $14(52)$ & & & \\
\hline No & $16(36)$ & & & $13(48)$ & & & \\
\hline Sum of diameters of hepatic metastases, $\mathrm{mm}$ & & 100 & 50 to 184 & & 114 & 76 & 0.833 \\
\hline \multicolumn{8}{|l|}{ Measurable extra-hepatic metastases } \\
\hline Number of metastases & & & & & & & 0.099 \\
\hline None & $24(54)$ & & & $19(70)$ & & & \\
\hline 1 & $11(24)$ & & & $7(26)$ & & & \\
\hline$\geq 2$ & $10(22)$ & & & $1(4)$ & & & \\
\hline Localization & & & & & & & 0.198 \\
\hline Peritoneum & $3(7)$ & & & $3(11)$ & & & \\
\hline Lung & $11(24)$ & & & $2(8)$ & & & \\
\hline Lymphadenopathy & $11(24)$ & & & $2(8)$ & & & \\
\hline Other & $3(7)$ & & & $1(4)$ & & & \\
\hline Vascular endothelial growth factor $(\mathrm{n}=69), \mu \mathrm{g} / \mathrm{L}$ & & 263 & 81 to 425 & & 253 & 229 & 0.280 \\
\hline WHO performance status $(\mathrm{n}=\mathbf{7 0})$ & & & & & & & 0.087 \\
\hline 0 & $24(54)$ & & & $9(33)$ & & & \\
\hline 1 & $19(42.5)$ & & & $16(59)$ & & & \\
\hline 2 & 0 & & & $2(8)$ & & & \\
\hline Combined chemotherapy & & & & & & & 0.762 \\
\hline FOLFIRI & $28(62)$ & & & $19(70)$ & & & \\
\hline FOLFOX & $5(11)$ & & & $2(8)$ & & & \\
\hline Others & $12(27)$ & & & $6(22)$ & & & \\
\hline BMI category, $\mathrm{kg} / \mathrm{m}^{2}$ & & 25.1 & 3.6 & & 22.9 & 3.9 & 0.019 \\
\hline Underweight $(<18.5)$ & $1(2)$ & & & $4(15)$ & & & \\
\hline Normal weight (18.5-24.9) & $21(47)$ & & & $16(59)$ & & & \\
\hline Overweight (25-29.9) & $18(40)$ & & & $6(22)$ & & & \\
\hline Obese $(>30)$ & $5(11)$ & & & $1(4)$ & & & \\
\hline \multicolumn{8}{|l|}{ Body composition parameters } \\
\hline Skeletal muscle Area $\left(\mathrm{cm}^{2}\right)$ & & 148.8 & 23.8 & & 97.5 & 13.9 & $<0.0001$ \\
\hline Skeletal muscle Index $\left(\mathrm{cm}^{2} / \mathrm{m}^{2}\right)$ & & 49.3 & 7.2 & & 37.4 & 5.3 & $<0.0001$ \\
\hline Sarcopenic patients & $28(62)$ & & & $21(78)$ & & & 0.201 \\
\hline Visceral adipose Area $\left(\mathrm{cm}^{2}\right)$ & & 154.0 & 101.7 & & 82.1 & 70.0 & 0.002 \\
\hline Subcutaneous adipose Area $\left(\mathrm{cm}^{2}\right)$ & & 111.2 & 75.4 to 151.0 & & 158.8 & 76.8 & 0.025 \\
\hline Total adipose Area $\left(\mathrm{cm}^{2}\right)$ & & 285.4 & 153.1 & & 252.8 & 139.6 & 0.369 \\
\hline Bone mineral density $\left(\mathrm{mg} / \mathrm{cm}^{3}\right)$ & & 152.0 & 119.1 to 173.1 & & 150.0 & 38.2 & 0.892 \\
\hline Osteopenic patients & $12(27)$ & & & $7(26)$ & & & 1.000 \\
\hline
\end{tabular}

Treatment response data are summarized in Table 4. We found no association between best tumor response to chemotherapy and the number of tissues lost. Therefore, change in diameter of identified hepatic metastases was not associated with the number of tissues lost. Among the 72 patients included, only one had an increase in tumor size (progressive disease) at two months from baseline.

\subsection{Secondary analyses}

Secondary analyses were performed to detect potential association of the number of tissues lost with overall survival and toxicities. These analyses can be regarded as exploratory, owing to limited sample size. Median overall survival didn't differ when comparing patients with zero or one tissue lost (n $=38,34.1$ months, $95 \%$ CI, 28.2 to 40.0 ) vs. patients with any two or three tissues lost ( $\mathrm{n}=34,28.5$ months, $95 \% \mathrm{CI}, 22.5$ to 34.5 , log-rank $\mathrm{p}=0.350)$ (Fig. S1).

We found no association between the frequency of toxicities, attributable to bevacizumab, and the number of tissues lost
(Table S1). Patients experienced toxicities with maximum grade 3. Most frequent adverse events were hypertension, low levels of hemoglobin and epitaxis (data not shown).

\section{Discussion}

Oncologic images have begun to be exploited secondarily, to extract information on body composition mainly including the mass and change over time of skeletal muscle and adipose tissues. Here, this is the first study to add CT-defined bone mineral density, and show that patients with colorectal cancer may show changes over time in these tissues individually or collectively. Changes in muscle, bone and fat during anti-cancer therapy show considerable inter-individual variation with substantial losses of one or more tissues in some individuals.

\subsection{Methodological considerations}

This was a secondary analysis of a clinical trial (STIC Avastin, NCT00489697), allowing us to present data on patients with uniform cancer site and stage and under a currently used treatment for this disease. 

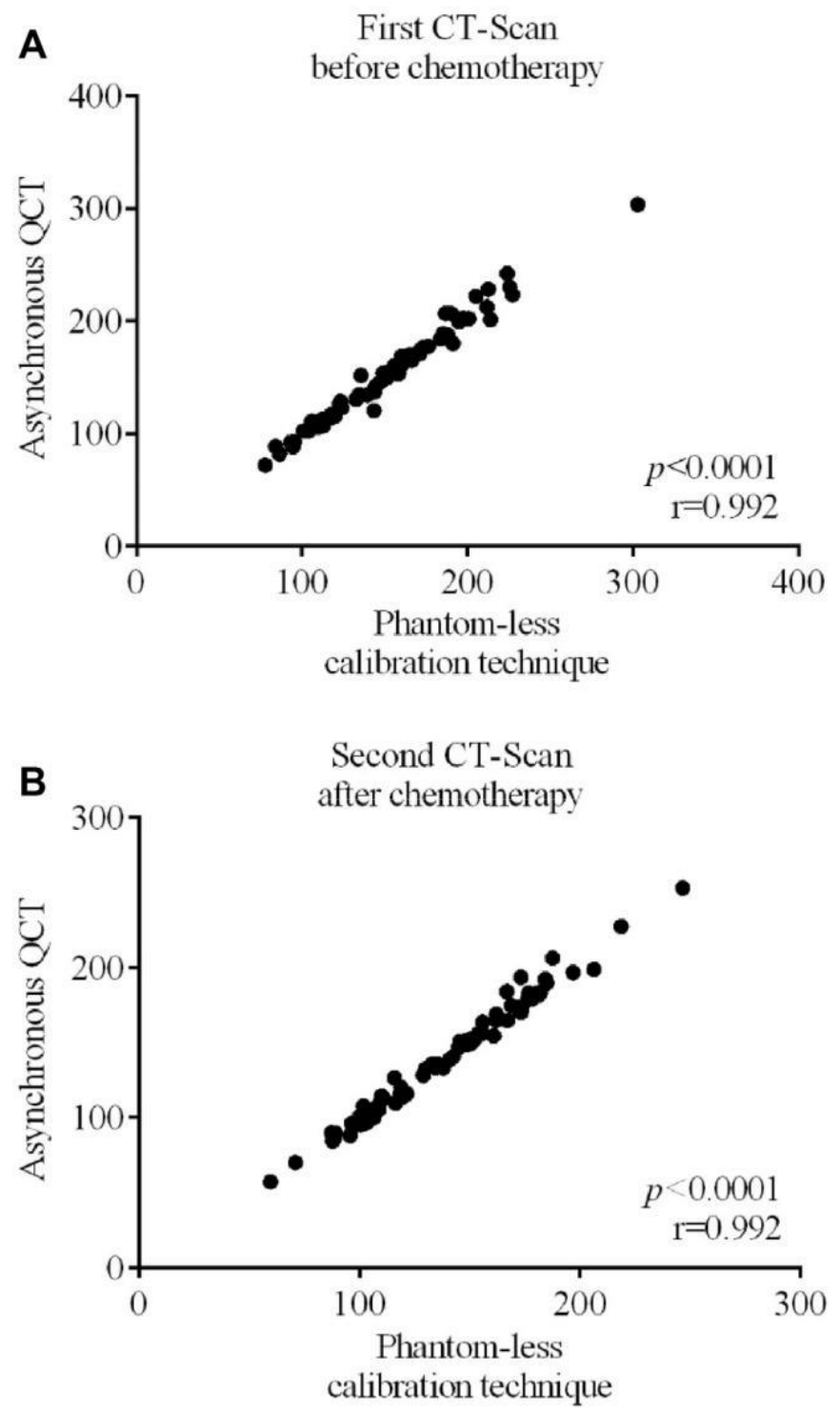

Fig. 3. Validation of the Phantom-less calibration technique to estimate Bone Mineral Density. Correlations of lumbar bone mineral density estimated with the phantom-less calibration technique and asynchronous QCT technique (A) at baseline and (B) after chemotherapy $(\mathrm{n}=72)$.

The study included detailed assessments of treatment response, adverse events and CT imaging. Our study is similar in this regard to that of KazemiBajestani et al. [1] in which a well-defined population of patients with metastatic non-small cell lung cancer treated with carboplatin-based therapies was evaluated for body composition changes over time. We used standardized assessments of CT muscle and fat that are accepted and widely used [35e39]. We additionally extracted mean lumbar spine bone mineral density from CT images; this has not previously been reported in conjunction with muscle and adipose tissue changes in any oncological patient population.

A limitation of our study is that the STIC Avastin investigation was not originally planned to include analyses of bone mineral density, and for that reason a reference phantom was not included in the imaging protocol. There are currently 3 techniques for studying bone mineral density on CT-Scanners, two of which use a reference phantom: a) Synchronous quantitative computed tomography (QCT) in which a phantom is placed directly under the subject during the scan [48];

b) Asynchronous QCT in which an external reference phantom is used. The use of an external phantom is currently often employed thanks to greater stability of x-ray output by modern CT-scanners. Several studies have shown a very good equivalence of BMD measurements obtained with DXA and asynchronous QCT [47], as well as synchronous and asynchronous QCT [46]. These methods should be considered for future, prospectively conducted studies.

c) Phantom-less technical calibration. The phantom-less calibration technique is based on known linear attenuation coefficients of subcutaneous adipose tissue and paraspinal muscle that can be used to estimate BMD $[43,44]$. This method can, however be affected by scanner instability, contrast injection, presence of fat within bone marrow or skeletal muscle, beam hardening artefacts and patient metal artifacts [51,52,55]. To address this limitation, we compared asynchronous QCT and phantom-less calibration technique across 4 CT-Scanners of different brands available in CHRU of Tours, with CT images at baseline and after chemo-therapy, confirming our results and increasing our confidence in this technique.

While this analysis included a homogenous population of clinical trialeligible subjects, sample size was constrained by missing or inadequate CT images for analysis and this was particularly limiting for subgroup analyses. Larger studies are required to confirm our findings.

\subsection{Muscle, bone and fat loss}

Cancer associated weight loss has generally been considered as loss of skeletal muscle and adipose tissue [35], without consideration of other organs. Yet a series of recent studies in animals [56] and clinically in patients with non-small cell lung cancer [1], or lung, pancreatic, and gastro-intestinal cancers [57], point to a pronounced atrophy of cardiac muscle. Experimental studies also suggest that colorectal cancer may be accompanied by bone loss in addition to muscle and fat wasting [58,59]. While the idea of a broader participation of multiple organs and tissues is developing [60], and changes in lumbar, hip and/or femoral neck bone density during cancer treatments have been highlighted several times in recent clinical studies [15e20], concurrent changes of muscle, adipose tissue and bone mineral density have not been assessed clinically.

In colorectal cancer patients with metastatic disease under bevacizumab-based chemotherapy treatment, we assessed changes in muscle mass, fat mass and BMD over an interval of 70 days. There is well known inter-individual variation in loss of muscle and fat over time in patients during cancer therapy $[1-4,8]$. We likewise noted tissue losses, as well as stable tissue mass and even a small degree of tissue gain in some individuals. Here, we classified each tissue as stable (within measurement error)/gained versus loss. Mean tissue loss in the losers was substantial (SMM -8.1\%, SD 4.1; TAT -13.3\%, SD 8.7; BMD -17.4\%, SD 7.5), and it would be of interest to determine if these losses aggravated over time. As shown in Table 1, the average time interval between the two CT-Scans to examine changes in skeletal muscle and adipose tissues during anti-cancer treatments is $\sim 3 \mathrm{e} 4$ months, while measurements of lumbar, hip and/or femoral neck BMD by DXA scans are commonly performed at 6 and 12 months after treatment. However, in our study we showed that significant changes in lumbar bone mineral density can already be observed within a relatively short period of time of $\sim 70$ days. 

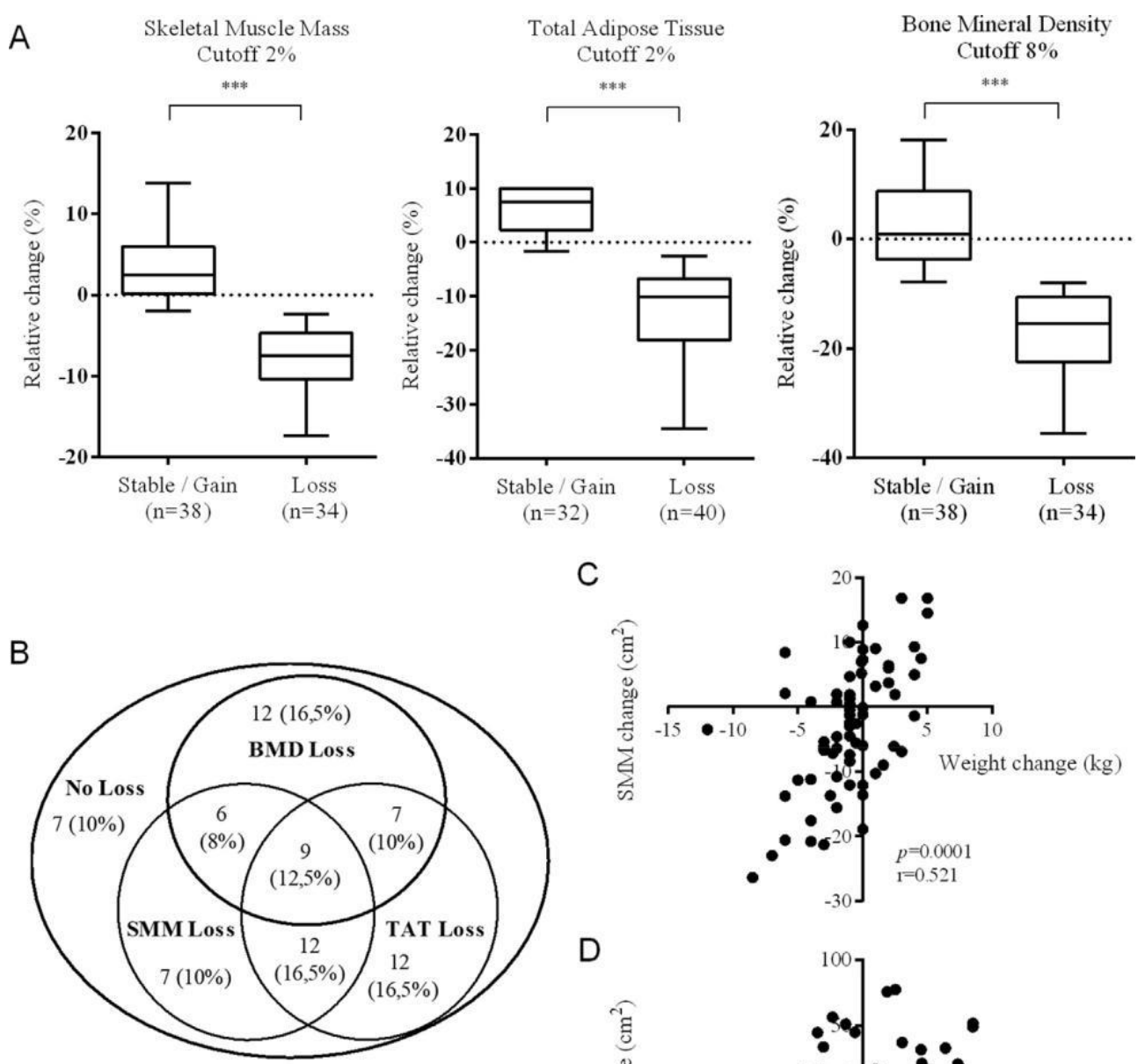

C
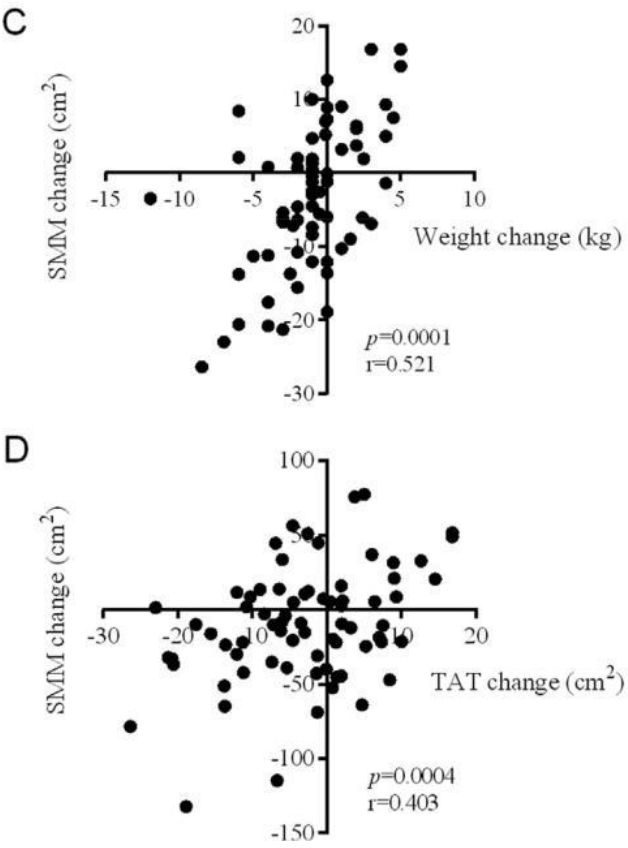

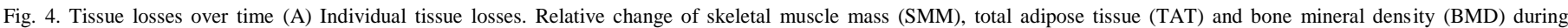

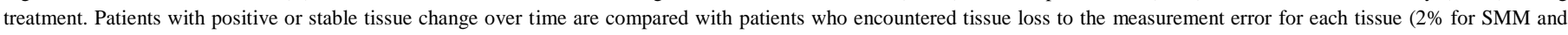

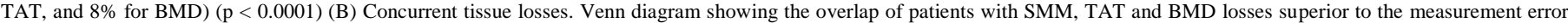

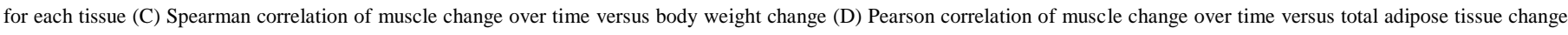
over time.

Around half of patients lost at least two tissues (16.5\% lost SMM + TAT, $8 \%$ lost SMM + BMD and 10\% lost TAT + BMD) and concurrent losses of skeletal muscle mass, total adipose tissue and bone mineral density were observed for $12.5 \%$ of patients. The drivers of this catabolic behavior remain to be fully elucidated. CRP, a well-known biomarker of cancer-associated wasting [1] was not available for patients in this sample and in future studies inflammatory catabolic effectors as well as molecules thought to be involved in bone-muscle-fat crosstalk would merit assessment.

We did not note any sexual dimorphism in the tissue losses described here. At baseline, we didn't see any sex difference in lumbar BMD. This result is consistent with other studies that have found little to no difference in lumbar BMD between the sexes in older men and women [55,61].

Our patients had very limited severity of bevacizumab related toxicity, and this toxicity was not related to multiple tissue loss.
We did not have access to toxicity data from the concurrent cytotoxic chemotherapy, as this was not part of the original intention of the study, and this is a limitation. However, the majority of patients (68\%) in this investigation had body composition features that correspond to the low risk category for toxicity of cytotoxic therapies as described by Ali et al. [62] so we could make the inference that there might have been little dose-limiting toxicity owing to the cytotoxic therapy in the current study. In Kazemi et al. study, simultaneous loss of skeletal muscle, cardiac muscle and adipose tissue was significantly related to progressive disease during therapy [1], however all patients in the STIC AVASTIN study had good disease control (stable disease or complete or partial response), so this potential driver of catabolic behavior was absent here. Our results do suggest that catabolism of multiple tissues is a manifestation of a more advanced disease, as it was associated with a higher burden of hepatic and extrahepatic metastases, as well as tumor biomarker VEGF. 
Table 4

\begin{tabular}{|c|c|c|c|c|c|c|c|}
\hline \multirow[t]{2}{*}{ Predictors } & \multicolumn{3}{|c|}{0 or 1 tissue loss $(n=38)$} & \multicolumn{3}{|c|}{2 or 3 tissues loss $(n=34)$} & \multirow[t]{2}{*}{$p$ value } \\
\hline & No. (\%) & $\begin{array}{l}\text { Mean } \\
\text { Median }\end{array}$ & $\begin{array}{l}S D \\
\text { IQR }\end{array}$ & No. (\%) & $\begin{array}{l}\text { Mean } \\
\text { Median }\end{array}$ & $\begin{array}{l}\text { SD } \\
\text { IQR }\end{array}$ & \\
\hline \multicolumn{8}{|l|}{ Patient characteristics } \\
\hline Age, years & & 64.1 & 9.9 & & 62.1 & 10.7 & 0.406 \\
\hline Sex & & & & & & & 0.185 \\
\hline Men & $21(55)$ & & & $24(71)$ & & & \\
\hline Women & $17(45)$ & & & $10(29)$ & & & \\
\hline $\operatorname{VEGF}(\mathrm{n}=69), \mu \mathrm{g} / \mathrm{L}$ & & 194 & 56 to 324 & & 287 & 106 to 511 & 0.060 \\
\hline \multicolumn{8}{|l|}{ Tumor mass } \\
\hline Primary colorectal tumor resected & $28(74)$ & & & $15(44)$ & & & 0.010 \\
\hline Presence of extra-hepatic metastases & $11(29)$ & & & $18(53)$ & & & 0.039 \\
\hline Number of extra-hepatic metastases & & & & & & & 0.004 \\
\hline 1 & $9(24)$ & & & $9(26)$ & & & \\
\hline$\geq 2$ & $2(5)$ & & & $9(26)$ & & & \\
\hline Best treatment response & & & & & & & 0.853 \\
\hline Complete response & $8(21)$ & & & $6(18)$ & & & \\
\hline Partial response & $19(50)$ & & & $17(50)$ & & & \\
\hline Progressive disease & $1(2.5)$ & & & 0 & & & \\
\hline Non-evaluable & $1(2.5)$ & & & 0 & & & \\
\hline
\end{tabular}

Values are expressed as mean \pm standard deviation (SD) or median with interquartile range (IQR).

\section{Conclusions}

We demonstrated that lumbar trabecular bone mineral density data could be extracted from standard oncologic CT images and that combined with measures of skeletal muscle area and total adipose tissue area, it could give a more complete view of patient's body composition. We showed considerable inter-individual variation with substantial losses of muscle, fat masses and BMD in some individuals, speaking to a generalized catabolic state in a limited duration interval, which appears to be associated with disease burden. Further studies are necessary to confirm and extend our results. These would ideally be conducted with a phantom during CT imaging and longer term studies of tissue evolution would be helpful in revealing the appearance of sarcopenia and osteopenia in patients with colorectal cancer.

\section{Author's contribution}

T. Lecomte was the principal investigator of STIC-Avastin study. Inclusion of patients: T. Lecomte, O. Bouché, C. Borg, E. Terrebonne, J-Y. Douillard.

Collection and assembly of data: R. Chautard,W. Raoul,D. Ternant,

J. Léger, A. Bleuzen.

CT image body composition analysis: A. Dolly.

Data analysis and interpretation: A. Dolly, VE. Baracos,

T. Lecomte, S. Servais, JF. Dumas.

Manuscript writing: A. Dolly, VE. Baracos, T. Lecomte, S. Servais,

JF. Dumas.

Manuscript editing and proofreading: All authors.

Final approval of manuscript: All authors.

\section{Funding}

This work was supported by INCa (Institut National du Cancer) and by the French Higher Education and Research Ministry under the program "Investissements d'avenir" Grant Agreement: LabEx MAbImprove ANR-10LABX-53-01. A. Dolly was supported by Research French Ministry and "Société Française de Nutrition Clinique et Métabolisme" (SFNCM, Exceptional Research Prize). VE Baracos received financial support from the Canadian Institutes of Health Research and the Alberta Cancer Foundation.

\section{Conflicts of interest}

The authors declare no conflict of interest.

\section{Acknowledgments}

Authors thank F. Tranquart, J. Drouillard, F. Patat, C. Roussel, PA. Dujardin, A. Fourmy, A. Fayault (INSERM CIC 1415, CHRU de Tours), C. Labbe-Devilliers (Department of Radiology, ICO René Gauducheau, SaintHerblain, France), Olivier Lucidarme (Department

of Radiology, Hôpital Pitie-Salpétrière, APHP, Paris, France), Jean-Pierre Tasu (Department of Radiology, CHU de Poitiers, France), Sylvain Manfredi (Department of Hepatogastroenterology and Digestive Oncology, CHU de Rennes, France), Christophe Aube (Department of Radiology, CHU d'Angers, France), Hervé Trillaud (Department of Diagnostic and Interventional Imaging, $\mathrm{CHU}$ de Bordeaux, France), Philippe Manzoni (Department of Radiology, CHRU de Besançon, France), Claude Marcus (Department of Radiology, CHU de Reims, France), and Céline Desvignes (University of Tours and Department of Pharmacology \& Toxicology, CHRU of Tours, France).

\section{Appendix A. Supplementary data}

Supplementary data to this article can be found online at https://doi.org/10.1016/j.clnu.2020.02.017.

\section{References}

[1] Kazemi-Bajestani SMR, Becher H, Butts C, Basappa NS, Smylie M, Joy AA, et al. Rapid atrophy of cardiac left ventricular mass in patients with non-small cell carcinoma of the lung. J Cachexia Sarcopenia Muscle 2019;10(5):1070e82. https://doi.org/10.1002/jcsm.12451.

[2] Palmela C, Velho S, Agostinho L, Branco F, Santos M, Santos MPC, et al. Body composition as a prognostic factor of neoadjuvant chemotherapy toxicity and outcome in patients with locally advanced gastric cancer. J Gastric Cancer 2017;17:74e87. https://doi.org/10.5230/jgc.2017.17.e8.

[3] Nattenmüller J, Wochner R, Muley T, Steins M, Hummler S, Teucher B, et al. Prognostic impact of CT-quantified muscle and fat distribution before and after first-linechemotherapy in lung cancer patients. PloS One 2017;12: e0169136. https://doi.org/10.1371/journal.pone.0169136. 
[4] Awad S, Tan BH, Cui H, Bhalla A, Fearon KCH, Parsons SL, et al. Marked changes in body composition following neoadjuvant chemotherapy for oesophago-gastric cancer. Clin Nutr 2012;31:74e7. https://doi.org/10.1016/ j.clnu.2011.08.008.

[5] Goncalves MD, Taylor S, Halpenny DF, Schwitzer E, Gandelman S, Jackson J, et al. Imaging skeletal muscle volume, density, and FDG uptake before and after induction therapy for non-small cell lung cancer. Clin Radiol 2018;73: 505.e1e8. https://doi.org/10.1016/j.crad.2017.12.004.

[6] Choi Y, Oh D-Y, Kim T-Y, Lee K-H, Han S-W, Im S-A, et al. Skeletal muscle depletion predicts the prognosis of patients with advanced pancreatic cancer undergoing palliative chemotherapy, independent of body mass index. PloS One 2015;10:e0139749. https://doi.org/10.1371/journal.pone.0139749.

[7] Benjamin AJ, Buschmann MM, Zhang SQ, Wroblewski K, Kindler HL, Roggin KK, et al. The impact of changes in radiographic sarcopenia on overall survival in older adults undergoing different treatment pathways for pancreatic cancer. J Geriatr Oncol 2018;9:367e72. https://doi.org/10.1016/ j.jgo.2018.03.002.

[8] Daly LE, Bhuachalla Eb Ní, Power DG, Cushen SJ, James K, Ryan AM. Loss of skeletal muscle during systemic chemotherapy is prognostic of poor survival in patients with foregut cancer. J Cachexia Sarcopenia Muscle 2018;9:315e25. https://doi.org/10.1002/jcsm.12267.

[9] Sasaki S, Oki E, Saeki H, Shimose T, Sakamoto S, Hu Q, et al. Skeletal muscle loss during systemic chemotherapy for colorectal cancer indicates treatment response: a pooled analysis of a multicenter clinical trial (KSCC 1605-A). Int J Clin Oncol 2019;24(10):1204e13. https://doi.org/10.1007/s10147-019-01460-8.

[10] Kurk SA, Peeters PHM, Dorresteijn B, de Jong PA, Jourdan M, Kuijf HJ, et al. Impact of different palliative systemic treatments on skeletal muscle mass in metastatic colorectal cancer patients. J Cachexia Sarcopenia Muscle 2018;9: 909e19. https://doi.org/10.1002/jcsm.12337.

[11] Blauwhoff-Buskermolen S, Versteeg KS, de van der Schueren MAE, den Braver NR, Berkhof J, Langius JAE, et al. Loss of muscle mass during chemo-therapy is predictive for poor survival of patients with metastatic colorectal cancer. J Clin Oncol 2016;34:1339e44. https://doi.org/10.1200/ JCO.2015.63.6043.

[12] Poterucha T, Burnette B, Jatoi A. A decline in weight and attrition of muscle in colorectal cancer patients receiving chemotherapy with bevacizumab. Med Oncol 2012;29:1005e9. https://doi.org/10.1007/s12032-011-9894-z.

[13] Antoun S, Bayar MA, Dyevre V, Lanoy E, Smolenschi C, Ducreux M. No evi-dence for changes in skeletal muscle mass or weight during first-line chemotherapy for metastatic colorectal cancer. BMC Canc 2019;19:847. https://doi.org/10.1186/s12885-019-6086-2.

[14] Lieffers JR, Mourtzakis M, Hall KD, McCargar LJ, Prado CM, Baracos VE. A viscerally driven cachexia syndrome in patients with advanced colorectal cancer: contributions of organ and tumor mass to whole-body energy de-mands. Am J Clin Nutr 2009;89:1173e9. https://doi.org/10.3945/ ajen.2008.27273.

[15] Lee SW, Yeo SG, Oh I-H, Yeo JH, Park DC. Bone mineral density in women treated for various types of gynecological cancer. Asia Pac J Clin Oncol 2016;12:e398e404. https://doi.org/10.1111/ajco.12584.

[16] Oostra DR, Lustberg MB, Reinbolt RE, Pan X, Wesolowski R, Shapiro CL. As-sociation of osteoprotegerin and bone loss after adjuvant chemotherapy in early-stage breast cancer. Mol Cell Endocrinol 2015;402:51e6. https:// doi.org/10.1016/j.mce.2014.12.028.

[17] Cameron DA, Douglas S, Brown JE, Anderson RA. Bone mineral density loss durin adjuvant chemotherapy in pre-menopausal women with early breast cancer: is it dependent on oestrogen deficiency? Breast Canc Res Treat 2010;123:805e14. https://doi.org/10.1007/s10549-010-0899-7.

[18] Hui SK, Khalil A, Zhang Y, Coghill K, Le C, Dusenbery K, et al. Longitudinal assessment of bone loss from diagnostic computed tomography scans in gy-necologic cancer patients treated with chemotherapy and radiation. Am J

Obstet Gynecol 2010;203(353):e1e7. https://doi.org/10.1016/ j.ajog.2010.06.001.

[19] Hadji P, Ziller M, Maskow C, Albert U, Kalder M. The influence of chemo-therapy on bone mineral density, quantitative ultrasonometry and bone turnover in pre-menopausal women with breast cancer. Eur J Cancer 2009;45: $3205 \mathrm{e} 12$. https://doi.org/10.1016/j.ejca.2009.09.026.

[20] Monroy-Cisneros K, Esparza-Romero J, Valencia ME, Guevara-Torres AG, Mendez-Estrada RO, Anduro-Corona I, et al. Antineoplastic treatment effect on bone mineral density in Mexican breast cancer patients. BMC Cancer 2016;16:860. https://doi.org/10.1186/s12885-016-2905-x.

[21] Waning DL, Guise TA. Cancer-associated muscle weakness: what's bone got to do with it? Bonekey Rep 2015;4:691. https://doi.org/10.1038/ bonekey.2015.59.

[22] Cianferotti L, Brandi ML. Muscleebone interactions: basic and clinical aspects Endocrine 2014;45:165e77. https://doi.org/10.1007/s12020-013-0026-8.

[23] Regan JN, Trivedi T, Guise TA, Waning DL. The role of TGFb in bone-muscle crosstalk Curr Osteoporos Rep 2017;15:18e23. https://doi.org/10.1007/ s11914-017-0344-5.

[24] Quinn LS, Anderson BG, Strait-Bodey L, Stroud AM, Argiles JM. Oversecretion of interleukin-15 from skeletal muscle reduces adiposity. Am J Physiol Endocrinol Metab 2009;296:E191e202. https://doi.org/10.1152/ ajpendo.90506.2008.

[25] Kandarian S. The molecular basis of skeletal muscle atrophy-parallels with osteoporotic signaling. J Musculoskelet Neuronal Interact 2008;8:340e1.
[26] Makki K, Froguel P, Wolowczuk I. Adipose tissue in obesity-related inflam-mation and insulin resistance: cells, cytokines, and chemokines. ISRN Inflamm 2013;2013:139239. https://doi.org/10.1155/2013/139239.

[27] Argiles JM, Lopez-Soriano FJ, Busquets S. Therapeutic potential of interleukin-15: a myokine involved in muscle wasting and adiposity. Drug Discov Today 2009;14:208e13. https://doi.org/10.1016/j.drudis.2008.10.010.

[28] Argiles JM, Lopez-Soriano J, Almendro V, Busquets S, Lopez-Soriano FJ. Cross-talk between skeletal muscle and adipose tissue: a link with obesity? Med Res Rev 2005;25:49e65. https://doi.org/10.1002/med.20010.

[29] Damrauer JS, Stadler ME, Acharyya S, Baldwin S, Couch ME, Guttridge DC. Chemotherapy-induced muscle wasting: association with NF-kB and cancer cachexia. Eur J Transl Myol 2008;28(2):158e66. https://doi.org/10.4081/ ejtm.2018.7590.

[30] Ibrahim MA, Bakhaat GA, Tammam HG, Mohamed RM, El-Naggar SA. Cardioprotective effect of green tea extract and vitamin E on Cisplatin-induced cardiotoxicity in mice: toxicological, histological and immunohistochemical studies. Biomed PharmacoTher 2019;113:108731. https://doi.org/10.1016/ j.biopha.2019.108731.

[31] Biondo LA, Batatinha HA, Souza CO, Teixeira AAS, Silveira LS, Alonso-Vale MI, et al. Metformin mitigates fibrosis and glucose intolerance induced by Doxorubicin in subcutaneous adipose tissue. Front Pharmacol 2018;9:452. https://doi.org/10.3389/fphar.2018.00452

[32] Ponnapakkam T, Katikaneni R, Nichols T, Tobin G, Sakon J, Matsushita O, et al Prevention of chemotherapy-induced osteoporosis by cyclophosphamide with a longacting form of parathyroid hormone. J Endocrinol Invest 2011;34: e392e7. https://doi.org/10.3275/7864.

[33] Tranquart F, Dujardin P-A, Bouche O, Marcus C, Borg C, Manzoni P, et al. Value of contrast-enhanced ultrasound quantification criteria for identifying pa-tients not responding to bevacizumab-based therapy for colorectal liver me-tastases. Ultraschall Med 2018;39:544e58. https://doi.org/10.1055/s-0043-122497.

[34] Eisenhauer EA, Therasse P, Bogaerts J, Schwartz LH, Sargent D, Ford R, et al. New response evaluation criteria in solid tumours: revised RECIST guideline (version 1.1). Eur J Cancer 2009;45:228e47. https://doi.org/10.1016/ j.ejca.2008.10.026.

[35] Fearon K, Strasser F, Anker SD, Bosaeus I, Bruera E, Fainsinger RL, et al. Defi-nition and classification of cancer cachexia: an international consensus. Lancet Oncol 2011:12:489e95. https://doi.org/10.1016/S1470-2045(10)70218-7.

[36] Prado CMM, Lieffers JR, McCargar LJ, Reiman T, Sawyer MB, Martin L, et al. Prevalence and clinical implications of sarcopenic obesity in patients with solid tumours of the respiratory and gastrointestinal tracts: a population-based study. Lancet Oncol 2008;9:629e35. https://doi.org/10.1016/S1470-2045(08)70153-0.

[37] Mourtzakis M, Prado CMM, Lieffers JR, Reiman T, McCargar LJ, Baracos VE. A practical and precise approach to quantification of body composition in cancer patients using computed tomography images acquired during routine care. Appl Physiol Nutr Metab 2008;33:997e1006. https://doi.org/10.1139/H08-075.

[38] Shen W, Punyanitya M, Wang Z, Gallagher D, St-Onge M-P, Albu J, et al. Total body skeletal muscle and adipose tissue volumes: estimation from a single abdominal crosssectional image. J Appl Physiol 2004;97:2333e8. https:/ doi.org/10.1152/japplphysiol.00744.2004.

[39] Mitsiopoulos N, Baumgartner RN, Heymsfield SB, Lyons W, Gallagher D, Ross R. Cadaver validation of skeletal muscle measurement by magnetic resonance imaging and computerized tomography. J Appl Physiol 1998;85: 115e22. https://doi.org/10.1152/jappl.1998.85.1.115.

[40] van Vugt JLA, Coebergh van den Braak RRJ, Schippers HJW, Veen KM, Levolger S, de Bruin RWF, et al. Contrast-enhancement influences skeletal muscle density, but not skeletal muscle mass, measurements on computed tomography. Clin Nut 2018;37:1707e14. https://doi.org/10.1016/ j.clnu.2017.07.007.

[41] Rollins KE, Javanmard-Emamghissi H, Awwad A, Macdonald IA, Fearon KCH, Lobo DN. Body composition measurement using computed tomography: does the phase of the scan matter? Nutrition 2017;41:37e44. https://doi.org/ 10.1016/j.nut.2017.02.011.

[42] Martin L, Birdsell L, Macdonald N, Reiman T, Clandinin MT, McCargar LJ, et al. Cance cachexia in the age of obesity: skeletal muscle depletion is a powerful prognostic factor, independent of body mass index. J Clin Oncol 2013;31:1539e47. https://doi.org/10.1200/JCO.2012.45.2722.

[43] Gudmundsdottir H, Jonsdottir B, Kristinsson S, Johannesson A, Goodenough D, Sigurdsson G. Vertebral bone density in Icelandic women using quantitative computed tomography without an external reference phantom. Osteoporos Int 1993;3:84e9. https://doi.org/10.1007/BF01623378.

[44] Boden SD, Goodenough DJ, Stockham CD, Jacobs E, Dina T, Allman RM. Precise measurement of vertebral bone density using computed tomography without the use of an external reference phantom. J Digit Imag 1989;2:31e8. https:/ doi.org/10.1007/BF03168013.

[45] Brown JK, Timm W, Bodeen G, Chason A, Perry M, Vernacchia F, et al. Asynchronously calibrated quantitative bone densitometry. J Clin Densitom 2017;20:216e25. https://doi.org/10.1016/j.jocd.2015.11.001.

[46] Wang L, Su Y, Wang Q, Duanmu Y, Yang M, Yi C, et al. Validation of asyn-chronous quantitative bone densitometry of the spine: accuracy, short-term reproducibility, and a comparison with conventional quantitative computed tomography. Sci Rep 2017;7:6284. https://doi.org/10.1038/s41598-017-06608-y. 
[47] Pickhardt PJ, Bodeen G, Brett A, Brown JK, Binkley N. Comparison of femoral neck BMD evaluation obtained using Lunar DXA and QCT with asynchronous calibration from CT colonography. J Clin Densitom 2015;18:5e12. https:// doi.org/10.1016/j.jocd.2014.03.002.

[48] Shepherd JA, Schousboe JT, Broy SB, Engelke K, Leslie WD. Executive summary of the 2015 ISCD position development conference on advanced measures from DXA and QCT: fracture prediction beyond BMD. J Clin Densitom 2015;18: $274 \mathrm{e} 86$. https://doi.org/10.1016/j.jocd.2015.06.013.

[49] American College of Radiology. ACR-SPR-SSR practice parameter for the per-formance of quantitative computed tomography (QCT) bone densitometry (amended 2014 resolution 39). Reston, Va, USA: American College of Radiology; 2008. https://www.acr.org/-/media/ACR/Files/Practice-Parameters/QCT.pdf.

[50] Brandes AA, Bartolotti M, Tosoni A, Poggi R, Franceschi E. Practical manage-ment of bevacizumab-related toxicities in glioblastoma. Oncologist 2015;20: 166e75. https://doi.org/10.1634/theoncologist.2014-0330.

[51] Randall LM, Monk BJ. Bevacizumab toxicities and their management in ovarian cancer. Gynecol Oncol 2010;117:497e504. https://doi.org/10.1016/ j.ygyno.2010.02.021.

[52] CTCAE. Common Terminology criteria for adverse events (CTCAE) | protocol development | CTEP. n.d, https://ctep.cancer.gov/protocolDevelopment/ electronic_applications/ctc.htm. [Accessed 23 June 2019].

[53] Caulet M, Lecomte T, Bouche O, Rollin J, Gouilleux-Gruart V, Azzopardi N, et al. Bevacizumab pharmacokinetics influence overall and progression-free sur-vival in metastatic colorectal cancer patients. Clin Pharmacokinet 2016;55: $1381 \mathrm{e} 94$. https://doi.org/10.1007/s40262-016-0406-3.

[54] MacDonald AJ, Greig CA, Baracos V. The advantages and limitations of cross-sectional body composition analysis. Curr Opin Support Palliat Care 2011;5: 342e9. https://doi.org/10.1097/SPC.0b013e32834c49eb.
[55] Naganathan V, Sambrook P. Gender differences in volumetric bone density: a study of opposite-sex twins. Osteoporos Int 2003;14:564e9. https://doi.org/ 10.1007/s00198-0031422-3.

[56] Olivan M, Springer J, Busquets S, Tschirner A, Figueras M, Toledo M, et al. Theophylline is able to partially revert cachexia in tumour-bearing rats. Nutr Metab 2012;9:76. https://doi.org/10.1186/1743-7075-9-76.

[57] Barkhudaryan A, Scherbakov N, Springer J, Doehner W. Cardiac muscle wasting in individuals with cancer cachexia. ESC Heart Fail 2017;4:458e67. https://doi.org/10.1002/ehf2.12184.

[58] Pin F, Barreto R, Kitase Y, Mitra S, Erne CE, Novinger LJ, et al. Growth of ovarian cancer xenografts causes loss of muscle and bone mass: a new model for the study of cancer cachexia. J Cachexia Sarcopenia Muscle 2018;9:685e700. https://doi.org/10.1002/jcsm.12311.

[59] Bonetto A, Kays JK, Parker VA, Matthews RR, Barreto R, Puppa MJ, et al. Dif-ferential bone loss in mouse models of colon cancer cachexia. Front Physiol 2016;7:679. https://doi.org/10.3389/fphys.2016.00679.

[60] Argiles JM, Stemmler B, Lopez-Soriano FJ, Busquets S. Inter-tissue communi-cation in cancer cachexia. Nat Rev Endocrinol 2018;15:9e20. https://doi.org/ 10.1038/s41574-0180123-0.

[61] Faulkner RA, McCulloch RG, Fyke SL, De Coteau WE, McKay HA, Bailey DA, et al. Comparison of areal and estimated volumetric bone mineral density values between older men and women. Osteoporos Int 1995;5:271e5. https:// doi.org/10.1007/BF01774017.

[62] Ali R, Baracos VE, Sawyer MB, Bianchi L, Roberts S, Assenat E, et al. Lean body mass as an independent determinant of dose-limiting toxicity and neuropathy in patients with colon cancer treated with FOLFOX regimens. Cancer Med 2016;5:607e16. https://doi.org/10.1002/cam4.621. 